\title{
Surface Water Management in Machhu Dam Command Area using Geo-Informatics Techniques
}

\author{
Satyendra Belwanshi \\ School of Electronics, \\ DeviAhilya University (DAVV) \\ Indore, MadhyaPradesh, India
}

\author{
M H Kalubarme \\ Bhaskaracharya Institute for \\ Space Application and Geo- \\ Informatics, (BISAG), \\ Gandhinagar, Gujarat, India
}

\author{
Khalid Mehmood \\ Bhaskaracharya Institute for \\ Space Application and Geo- \\ Informatics, (BISAG), \\ Gandhinagar, Gujarat, India
}

\begin{abstract}
Water is the most important natural resource; it is the most basic human need and a valuable national asset. Water is one of nature's most important gifts to mankind. Efficient development and optimized utilization of water resources therefore, is of great significance to the overall development of the country. In Rajkot district (India) the Machhu Dam was built for supplying drinking water to urban areas. The present study on Surface Water Management in Machhu Dam Command Area (Rajkot District) using Geo-Informatics Techniques was carried out in the Aji and Machhu dam Catchment areas, using Indian Remote Sensing Satellite digital data and Geoinformatics technology. The surplus water availability in major reservoirs and dams was computed from the data collected from Flood Control Cell (FCC) government of Gujarat. It was observed from the FCC data analysis, the Machhu river have surplus water during 2007-2011.Therefore, this study on diverting of surplus water through canals, ponds and check dams in the study area was carried out. The remote sensing data and GIS data was used to generate present land use, drainage pattern as well as slope and contour using 3-D technology. This analysis was carried out for diverting surplus water through proposed canal and pond. The result of the study indicate that if the surplus water from the Machhu dam is diverted to the unirrigated areas in Rajkot district, it will definitely improve the agricultural production due to availability of irrigation water through canal. The improvements in agricultural production will help to improve the economical condition of the farmers in the region.
\end{abstract}

\section{Keywords}

Indian Remote Sensing Satellite (IRS), Cartosat, LISS-III, LISS-IV Data, Digital Elevation Model (DEM), Canal Alignment, Geographic Information system (GIS), Surface Water Management

\section{INTRODUCTION}

Water is the most important natural resource; it is the most basic human need and a valuable national asset. Water is one of nature's most important gifts to mankind. Efficient development and optimum utilization of water resources, therefore, is of great significance to the overall development of country. Water plays a crucial role in the socio-economic development of India. Water has also become a major constraining factor for the growth of agricultural and industrial sectors. Water is an essential natural resource that shapes regional landscapes and is vital for ecosystem functioning and human well- being.

Our planet is also facing a water crisis in public health: more than a billion people in developing nations lack access to safe drinking water, and more than 2 billion lack, proper sanitation. And in near future, water shortages are likely to spread into other key sectors-notably agriculture and energy. Global energy demand is projected to increase $57 \%$ by 2030 , and water demand for food production might easily double.

Surface water is that portion of water collected on the ground or in a stream, river, lake, wetland or ocean. Surface water is naturally replenished by precipitation and naturally lost through discharge to the oceans, evaporation and sub-surface seepage. Although the only natural input to any surface water system is precipitation within its watershed, the total quantity of water in that system at any given time is also dependent on many other factors. These factors include storage capacity in lakes, wetlands and artificial reservoirs, the permeability of the soil beneath these storage bodies, the runoff characteristics of the land in the watershed, the timing of the precipitation and local evaporation rates. All of these factors also affect the proportions of water lost. Natural surface water can be augmented by importing surface water from another watershed through a canal or pipeline. Humans can also cause surface water to be lost (i.e., become unusable) through pollution.

The surplus water of Machhu dam can be diverted to the deficit basins of Aji in the saurashtra region of Gujarat. Linking of Basins through canals is not a new concept, but has been in practice since times immemorial. The present Sardar Sarovar project supplying Narmada river waters to the 4 states of Gujarat, Madhya Pradesh, Maharashtra and Rajasthan had been successfully implemented. These basins, rich in both ground water and surface water resources are the potential water resource-donor basins to the water resource deficit basins. In the year 2009 the rainfall is quite erratic and recorded only $30 \%$ of annual rainfall in 280 districts in India. The agricultural drought was declared in 280 districts out of 593 in India in the year 2009. The drought affected area would be nearly $50 \%$ in the country every year. The situation demands an efficient and judicious management of available water resources for optimum utilization and their sustainability for the food and observed security of posterity. The present study has to do with the surplus water diversion and its environmental impact on execution. It was found on the field that an increase in irrigated land after the surplus water diversion to the unirrigated areas where water scarcity exists, the surplus water released to the selected sites will be beneficial and helpful to improve the agricultural productivity as well as some industries which use large amount of water. Based on data analysis of Remote Sensing, spatial data and Flood Control Cell Data analyses, suitable sites for canal have been identified in this study area \& excess water can be diverted through Natural Drainage and Canal. 


\subsection{Canal Alignment Using Geographic Information System}

Occurrence of prolonged droughts and floods in various parts of the country is primarily due to the improper management of water resources, which also hinders the growth of the nation. The massive task of interlinking rivers through canals requires multidisciplinary investigation on hydrological, agricultural, social and economic factors that can be studied using GIS and remote sensing. The procedure adopted by Majunu and Sumanth Kumar ,2005 in Ootacamund uses specific data processing functions in GIS to facilitate the canal layout based on physical \& economic factors. The digital information on topography, contours, soils type, drainage pattern are obtained from toposheet and the landuse pattern from LISS-3 and PAN imagery and stored in database. Digital elevation model (DEM) was extracted by interpolation from contour lines and used for horizontal and vertical alignment of canal. GIS being a powerful analysis and database tool, the stored data are available for easy retrieval, updation and analysis so that a "Decision Support System (DSS)" can be developed for future use. Also suitable alternatives would be identified to solve practical problems involved in the construction of canal.3D GIS has brought a boon in the present scenario in many aspects. Canal Alignment using 3D-GIS benefits in avoiding the various preliminary surveys associated to it, which ultimately reduces the capital and time.

\section{OBJECTIVES}

The major objectives of this study are as follows:

1. Study of surplus water in AJI dam and MACHHUII dam using Flood Control Cell Data.

2. Identification of canal, lake and check dams in the study area for planning of surplus water diversion.

3. Generation of contour \& slope using Cartosat DEM data.

4. Canal Alignment for diversion of excess water from Machhu dam to lakes, canals/ponds in the drought affected areas, using Geo-Informatics.

\section{STUDY AREA}

The machhu basin is situated between 22.10 to 23.10 degree North Latitude and 70.40 to 71.15 degree East Longitude. Machhu along with its tributaries flows $52 \%$ in the hilly area and $48 \%$ in plain region. The rivers fertilize Malia, Morbi, Wankaner, Jasdam \& Rajkot talukas of Rajkot districts and part of chotila taluka in surendranagar district.

Machhu river originates from the hill ranges of Jasdan Sardar and Mandva in Rajkot district \& chotila in Surendranagar district \& flows in north westerly direction along the district boundary of surendranagar and Rajkot up to village Beti and then flows mostly towards north in Rajkot district \& finally disappears near Malia in little Rann of Kachchh.This is one of the north flowing rivers of Saurashtra in Gujarat State. The location map of the study area is given in Figure-1
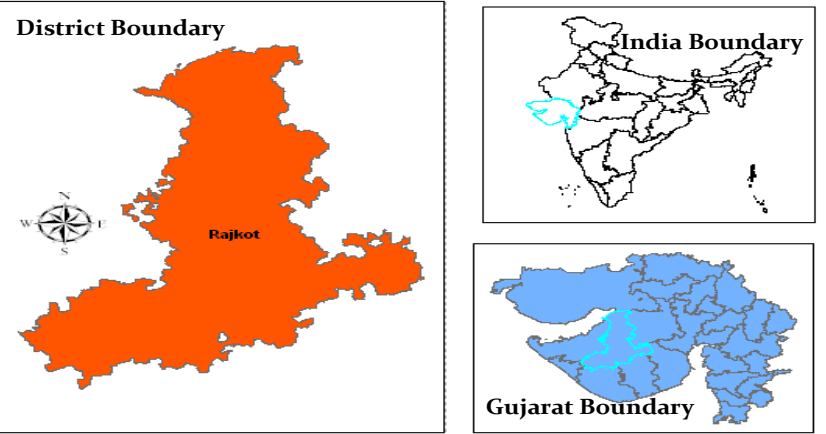

Figure 1: Location Map of the Study Area

\section{Methodology}

In this study, Indian Remote Sensing Satellite Digital Data (LISS-III, LISS-IV, Cartosat) from the year 2006, 2011 images had been used. In addition Flood Control Cell Data has been used, which is provided by Flood Control Cell (FCC) Government of Gujarat. This data centre also gives data about surplus water in the dams in Gujarat State. From this data, surplus water released from MACHHU-II Dam during 2007-2011 periods was extracted from this study. In this study, four stages were applied collection (Statistical Data (FCC)), Satellite Image Processing, Digitization on satellite images like (canal, river \& lake) and Spatial Analyzes. This research was accomplished by using the ArcGIS 9.3, ArcScene, ArcView (3-DAnalyst and Spatial Analyst Extension) ENVI 4.0 processing software. The Methodology flow chart is given in Figure-2

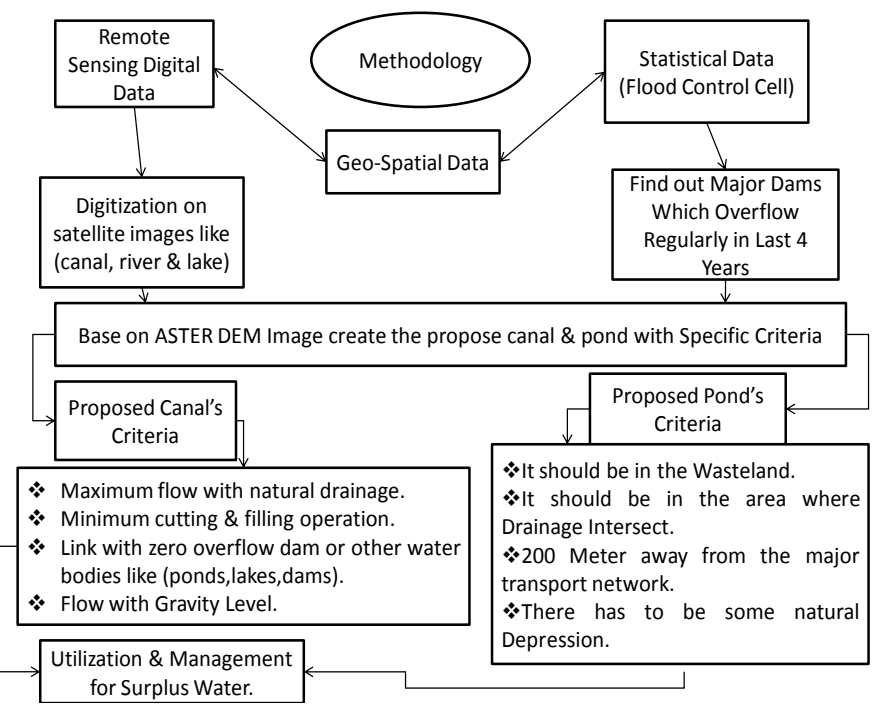

Figure 2: Methodology Flow Chart Figure

\subsection{Flood Control Cell (FCC) Data Analysis}

From the Flood Control Cell (FCC) data on various parameters, the surplus water released from the dams in the rivers is compiled. According to the data, during 2007-2011 large amount of water was released in rivers from various dams in Gujarat state. The data is presented in the table-1 \& table-2. 
Table 1. Flood Control Cell (FCC) Data of Machhu-2 Dam in Rajkot

\begin{tabular}{|c|c|c|c|c|}
\hline Scheme & Year & Inflow & $\begin{array}{c}\text { Cusec } \\
\text { River }\end{array}$ & $\begin{array}{c}\text { Cusec } \\
\text { Canal }\end{array}$ \\
\hline Machhu-2 & 2007 & 97135 & 0 & 100 \\
\hline Machhu-2 & 2008 & 197669 & 60000 & 500 \\
\hline Machhu-2 & 2010 & 119737 & 92745 & 700 \\
\hline Machhu-2 & 2011 & 1939 & 0 & 0 \\
\hline
\end{tabular}

Table 2. Flood Control Cell (FCC) Data of Aji-1 Dam in Rajkot

\begin{tabular}{|c|c|c|c|c|}
\hline Scheme & Year & Inflow & $\begin{array}{c}\text { Cusec } \\
\text { River }\end{array}$ & $\begin{array}{c}\text { Cusec } \\
\text { Canal }\end{array}$ \\
\hline Aji-1 & 2007 & 39640 & 4000 & 0 \\
\hline Aji-1 & 2008 & 11249 & 0 & 0 \\
\hline Aji-1 & 2010 & 7810 & 130 & 0 \\
\hline Aji-1 & 2011 & 104 & 0 & 0 \\
\hline
\end{tabular}

\subsection{Satellite Data Analysis}

Indian Remote Sensing Satellite (IRS P-6) LISS-III, LISS-IV, CARTOSAT-2 digital data used. The IRS P-6 digital data was geo-referenced and the mosaics were created in ENVI 4.0, the study area buffer and the command area is overlaid on the LISS-IV mosaic data of scene which covers the study area.

\subsection{Geo-Spatial Data}

Various GIS layers like Transport Network, Water Bodies, Land Use and village Boundary superimposed to satellite data. These GIS layers are given in Figure-3 \& Figure-4

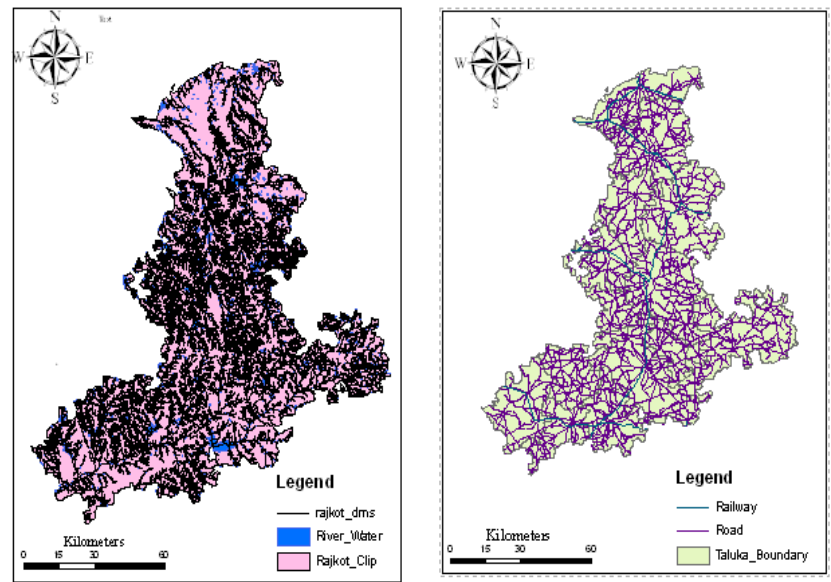

Figure 3: Spatial Data of Rajkot District

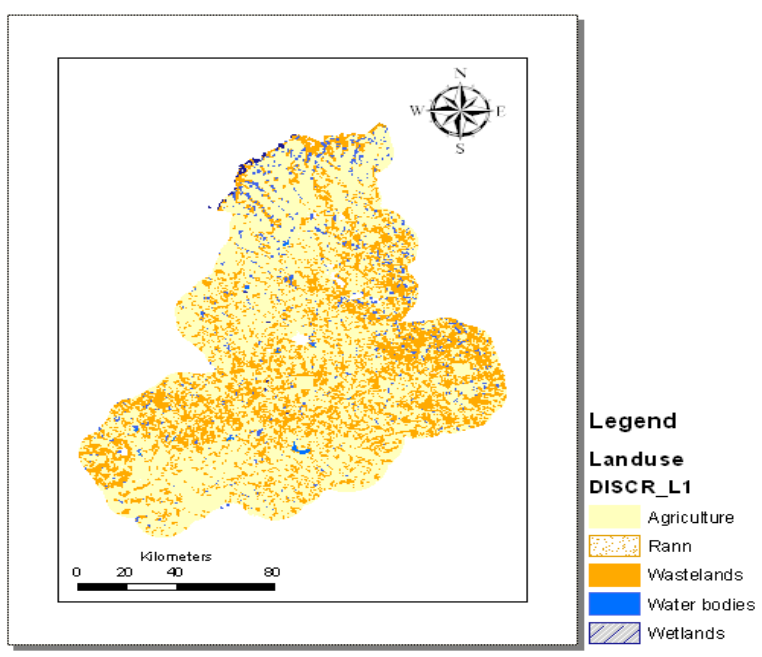

Figure 4: Land Use Map of the Rajkot District

\subsection{Remote Sensing Data Analysis}

\subsubsection{Area of interest (AOI) Extraction}

Indian remote sensing satellite data covering Rajkot district was georeferenced and district boundary were superimposed. Using this district boundary data area covering under Rajkot district was extracted from the full scene data. The satellite data along with district boundary is shown in figure. The extracted area of Rajkot District from the full scene data in shown in Figure-7

\subsubsection{ASTER Image Analysis}

The Aster elevation model (DEM) data with $30 \mathrm{~m}$ resolution was downloaded from the USGS website. This DEM data was registered with IRS-P6 LISS-III digital data. Aster DEM of Rajkot district is shown in figure. From this DEM data contour of $2 \mathrm{~m}, 5 \mathrm{~m}, 10 \mathrm{~m}$ intervals were generated. The drainage in this DEM digital data was identified and the flow directions along the slope were demarcated. The DEM data covering Rajkot district is given in Figure-5.

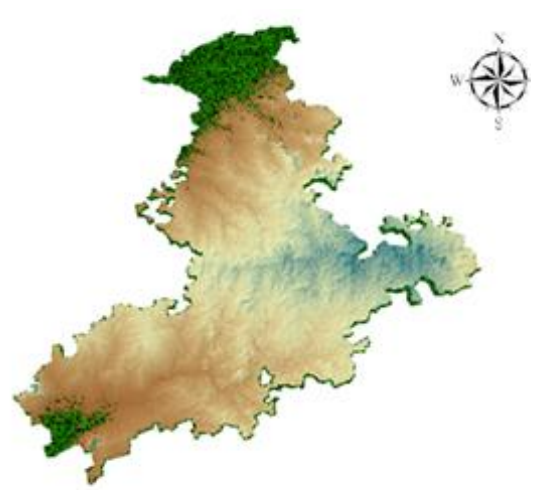

Figure 5: ASTER DEM Data of Rajkot District 


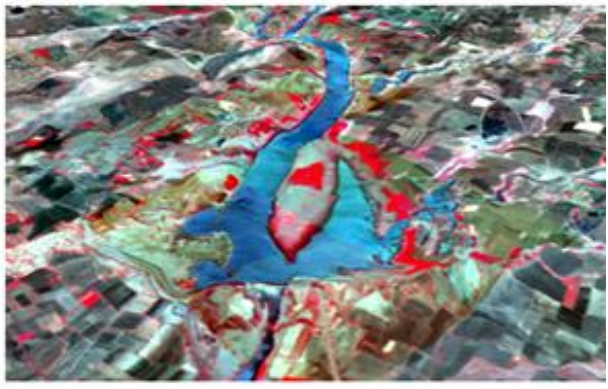

Figure 6: ASTER DEM Image showing Undulated Terrain

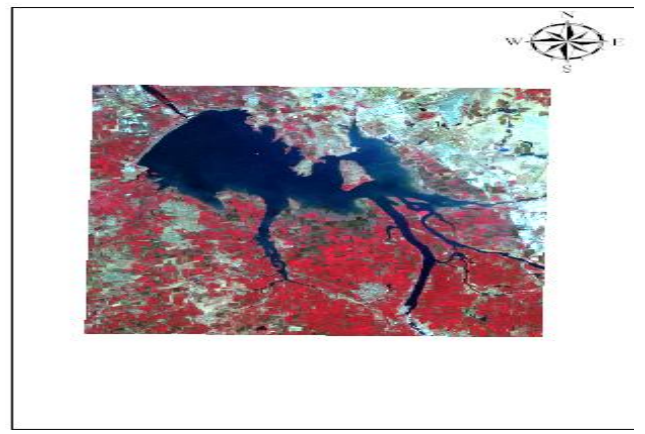

Figure 7: IRS P-6 LISS-III FCC Area of Interest (AOI) of MACHHU-II Dam in Rajkot District

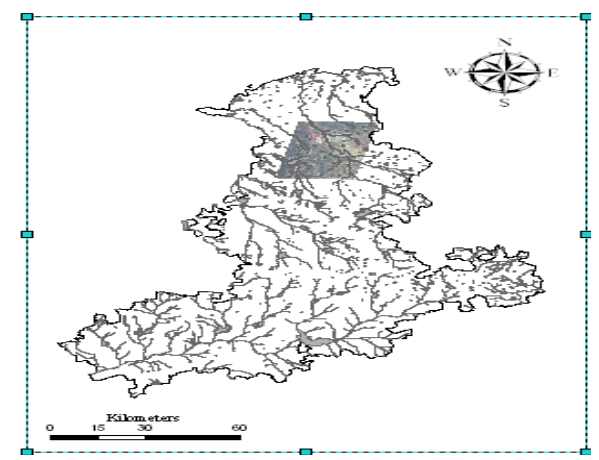

Figure 8: IRS P-6 LISS-IV of MACHHU-II Reservoir in Rajkot District

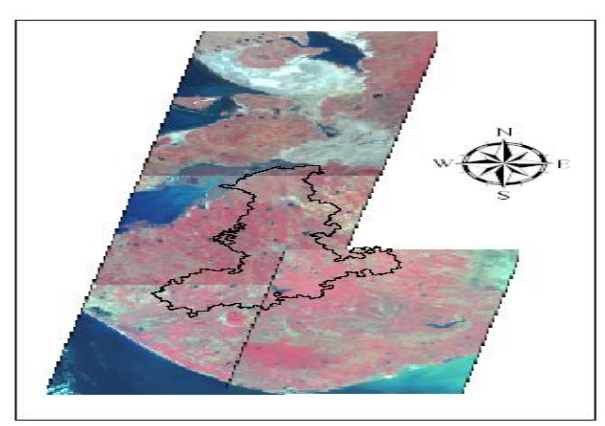

Figure 9: IRS P-6 LISS-III Dec.2011

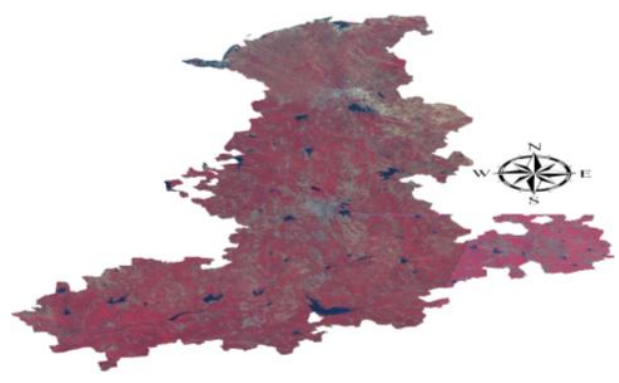

Figure 10: IRS P-6 LISS-III Dec.2011

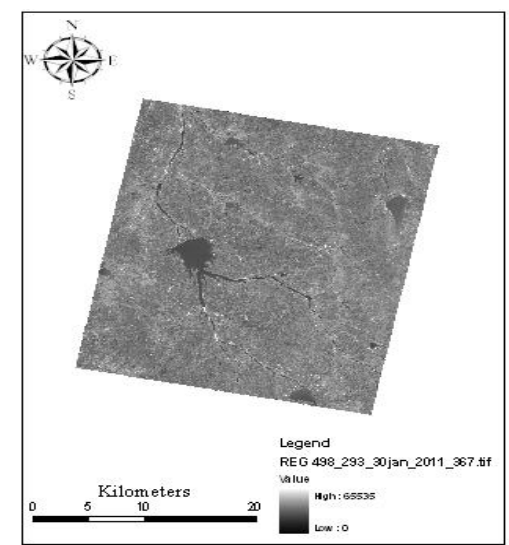

Figure 11: Cartosat-2 30 January 2011

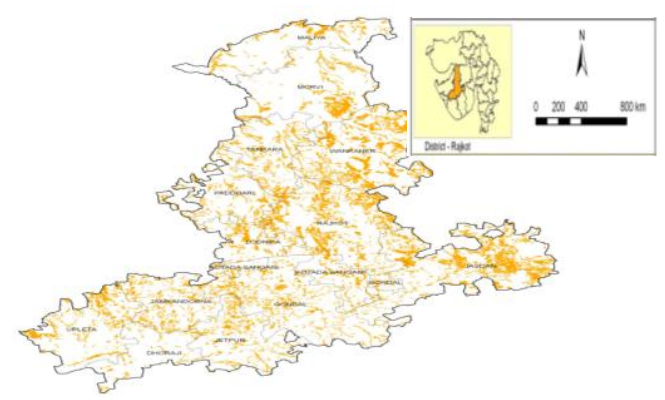

Figure 12: Wasteland in Rajkot District

\section{RESULTS \& DISCUSSION}

\subsection{Surplus Water Availability Analysis}

Flood Control Cell (FCC) Government of Gujarat, collects and maintain data on surface water, water quality of all major and minor dams information. The data Analysis of FCC indicate that, MACHHU-II Reservoir in Rajkot District, Gujarat State was surplus water during 2007-2011. The result of this analysis are shown in Figure-13.This indicates that in MACHHU-II reservoir surplus water is available and which can be diverted to the unirrigated areas where water scarcity exists, the surplus water released to the selected sites will be 
beneficial and helpful to improve the agricultural productivity as well as some industries which use large amount of water. Based on Data analysis of Remote Sensing, Spatial Data and Flood Control Cell Data analyzes, Sites for canal have been identified in this study area \& excess water can be diverted through Natural Drainage and Canal.

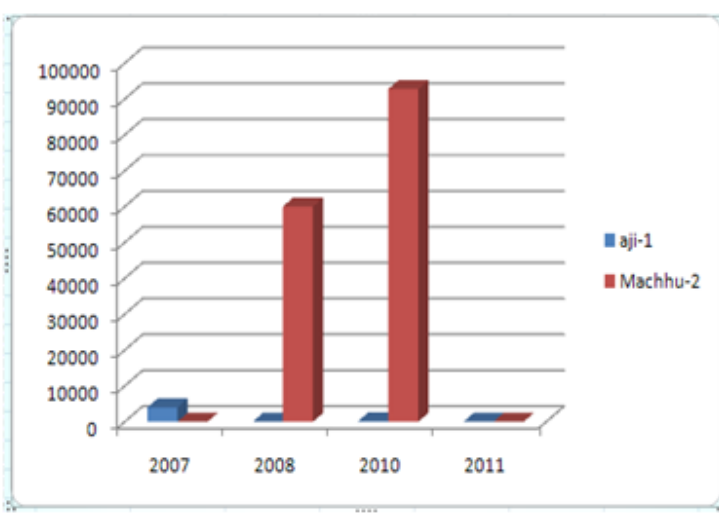

Figure 13: Surplus Water Released in AJI \& MACHHU Dam in Saurashtra

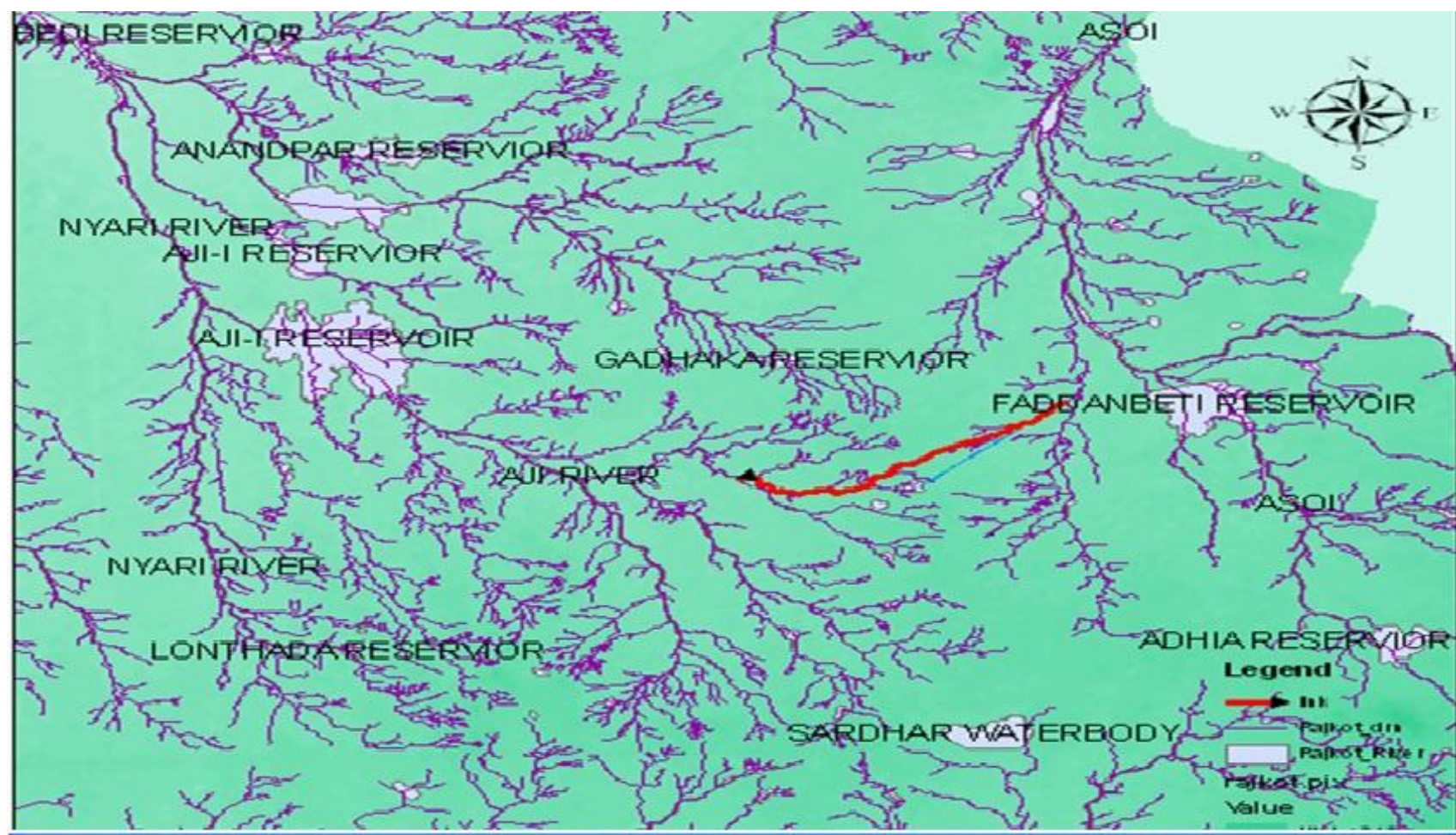

Profile Graph Title

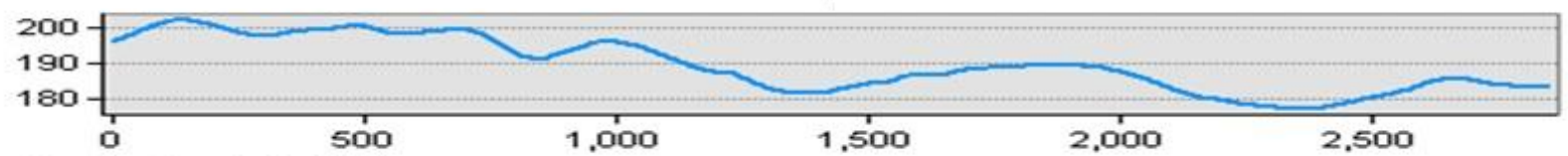

profile Graph Swotitie

Figure 14: Excess Water Diversion through Natural Drainage and Canal

\subsection{Basic Criteria for diverting the surplus water through proposed canal}

For diverting surplus water from the dams to the areas in study districts where acute shortage of water is experienced throughout year, such area will be more benefited by diverting the surplus water from major dams through either new canal system or the existing drainage and canals. Therefore, in the present study remote sensing data along with ASTER DEM data is analysed.For Canal Alignment the basic criteria for alignment of proposed canal system in the study area are as follows:

i. Based upon slope and contour derived from ASTER data, the area having natural gradients is identified so that the water flows with the gravity level.

ii. The other dams in the study area where there is no surplus water is identified. So that the surplus water 
released from the major dams flow through the other water bodies like pond, lake and small dams.

iii. The most important economic aspect of canal alignment is avoiding such undulated areas where cutting and filling operations are required so the area selected should have minimum cutting and filling operations which reduced the cost of the project.

iv. The most important aspect of diverting surplus water is through the natural drainage so that minimum land acquisitions are required.

\subsection{Proposed Canal Alignment based on analysis of contours and slopes}

ASTER DEM digital data with $30 \mathrm{~m}$ resolution was used for generating contours and slopes. The natural drainage derived from IRS LISS-III data was superimposed on Aster data. Figure-15 shows contour in the study area. Based upon this data analysis the areas, where the natural drainage can be connected with the proposed canal were identified and the length of the canal was calculated for this proposed canal. A profile analysis was carried out in ARCGIS. The profile analysis indicates cutting and filling operations required in the canal system for the natural flow of the water.

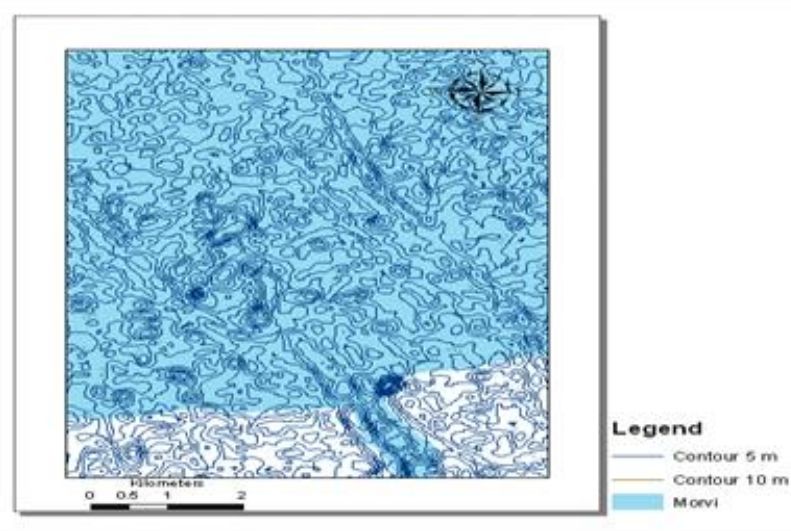

Figure 15: Contours derived from ASTER DEM data

\subsection{Cut and Fill Section}

The process involves removing earth from one part of the site and placing it in another part. A cut and fill is a procedure at construction sites to level slopes and create cuttings, canals, and embankments by removing earth from one point and using it as a fill in another. Cut and fill techniques have several distinct benefits, the most attractive of which are the time and cost savings the process offers. Transporting fill material to a construction site is time consuming and can add significantly to the overall project expense.

\subsection{DEM Generation \& Visualization}

According to the study carried out by K.Jacobsen on DEM generation of satellite data Digital Elevation Models (DEM) are required for several tasks like generation of orthoimages ,flood planning, erosion control, agriculture, generation of contour lines, visibility check, 3-D views and others. DEM can be generated by traditional photogrammetry based on aerial photos if they are available and not classified, but also very often more economic by means of space images. Another possibility is the use of airborne laser scanning - this will lead to very detailed and accurate information, but it is expensive.
Using Arc GIS 9.3 software, DEM can be generated automatically. It reflects the physical reality of the complete viewing geometry and corrects distortions that occur in the imaging process due to platform, sensor, earth, and cartographic projection conditions. After models are computed for the images, a pair of quasi-epipolar images is generated from the images in order to retain elevation parallax in only one direction. An automated image-matching procedure is used to generate the DEM through a comparison of the respective gray values of these images.

It also provides terrain conditions along with undulations \& valley which helps in identifying the areas which should be avoided for canal alignment. This also gives the idea about the shortest path for canal alignment with minimum cost requirement at the same time avoiding the good fertile agriculture land. 3-D visualization can also help in areas which will be benefited by proposed canal system.

\section{CONCLUSION}

The present study on "Surface Water Management in MACHHU Dam (Rajkot District) Command Area Using GeoInformatics Techniques" uses Indian Remote Sensing Satellite digital Data and geo-informatics technology. The surplus water availability in reservoirs \& dams was computed from the data collected from Flood Control Cell (FCC) Department of Gujarat. Indian Remote Sensing Satellite Digital Data, Spatial Data, Flood Control Cell (FCC) Data was analyzed. For Availability of Excess Water was identified from FCC Data. It was observed from the FCC data analysis, MACHHU-II Dam have surplus water during 2007-2011.so diverting the surplus water through canal, pond \& check dams in the study area, the present study was carried out. The remote sensing data (IRS P6 LISS-III, IV and CARTOSAT) \& GIS data was used to generate the landuse. Canal Alignment joining to Natural Drainages was performed using 3-D Technology. The Profile Graph of the Canal Alignment indicates the sites Elevation where Cutting \& Filling Operations has to be done.

\section{Major Conclusions of this Study are as follows:}

i. The flood control cell FCC data analysis indicated that in Machhu dam the surplus water was the highest during the period of 2007 to 2011 which was normally released in the river.

ii. Remote sensing data from IRS P-6 LISS-III and ASTER DEM data was analyzed in the present study for diverting surplus water through the natural drainage and proposed canal system.

iii. The slopes and Contours were generated using ASTER DEM data for Canal Alignment so that the water is diverted to the ponds and dams.

\section{ACKNOWLEDGMENTS}

Satyendra Belwanshi would like to express our gratitude to all those who gave the possibility to complete this research work. It gives me a great pleasure to thank Mr. T.P. Singh, Director Bhaskaracharya Institute for Space Application \& GeoInformatics, Gandhinagar who helped to a great extent in the research work. I am deeply indebted to Dr. M.B. Potdar (Project Director, BISAG, Gandhinagar), Mr.Sumit Prajapati (Project Scientist, BISAG, Gandhinagar and Mr. Nayan Patel (Project Scientist, BISAG, Gandhinagar) whose help, stimulating suggestions, knowledge, experience and encouragement helped me in analysis of the data and research 
work. I thank all members of BISAG for their suggestions \& help.

I would like to thank Dr. Raj Kamal, Dr.Abhay Kumar, Head ,School of Electronics, Dr. Sumant Katiyal , Senior Professors of School of Electronics, Devi Ahilya University, Indore (M.P) and Mrs. Pratibha M.Umale (Class Coordinator of SIT) for giving me an opportunity to work in such a prestigious Institute like BISAG. I am grateful to all our faculty members of School of Electronics Department for their suggestions and constant encouragement.

Last but not least, I would like to pay high regards to my Parents, Family Members, all Friends for their sincere encouragement and inspiration throughout my research work.

\section{REFERENCES}

[1] Leipnik, M.R., Kemp, K.K., Loaiciga, H.A., 1993. Implementation of GIS for water resources planning and management. J. Wat. Resour.Plan. Mgmt 119 (2), 184205

[2] Majunu S and Sumanth Kumar G (2006). Canal Alignment using Geographic Information System: Ecologists wake up! Curr. Sci., 87(8): 1030 - 1031.

[3] Rajiv K. Gupta (2004). "Water Governance in Gujarat State, India" , International Journal of Water Resources Development , 20(2):131-147.

[4] Rajamani V (2005). Interlinking of rivers: is it a solution? The Hindu, 26th August 2005.

[5] Jacobsen,K. DEM generation from satellite data.Germany.

[6] Kovar , K. and H.B. Nachtnebel (Eds) 1993.Application of Geographic Information System in hydrology and water resources management,IAHS Publication No.211. International Association of hydrological Sciences Press, Wallingford

[7] Ali, M. H., L.T. Shui, W.R. Walker: 2003. Optimal Water Management for Reservoir Based Irrigation Projects Using Geographic System. Journal of Irrigation and Drainage Engineering. 129(1):1-10.

[8] Khare, D., Garg, P.K., Jat, M.K. and Dhore K., (2007), Selection of Optimum Canal Alignment Using GIS: River Interlinking Perspective, Indian Journal Power and River Valley Development, March-April, 112-121.

[9] Abrams. M. and Hook, S.J. (1995): Simulated ASTER data for geological studies.IEEE Transactions on Geoscience and Remote Sensing, 33: 692-699.

[10] Lang, H.R. and Welch, R. (1999): Algorithm Theoretical Basis Document for ASTER Digital Elevation Models (Standard Product AST14) Version 3.0. NASA EOS Publication ATBD.

[11] Van Deursen, W.P.A. \& Kwadijk, J.C.J (1993) RHINEFLOW: an integrated GIS water balance model for the river Rhine. In: Application of Geographic
Information Systems in Hydrology and Water Resources (ed, by K. Kovar \& H. P. Nachtnebel) (Proc, Int. Conf. HydroGIS'93 , Vienna, April 1993), 507-518. IAHS Publ. no. 211

[12] Alumini Association, CEG Anna University, Proceedings of the seminar on Interlinking of Peninsular Rivers, February, 1999.

[13] Baban, S. (1999). "Use of remote sensing and geographical information systems in developing lake management strategies." Hydrobiologia 395-396(0): 211226.

[14] Dasmunsi, P. R. (2005). "National Water Convention on Inter-Basin Transfer of Water in India." International Journal of Environmental Consumerism 1 (1): 58-59.

[15] Wu, S., J. Li, et al. (2007). "Characterization and Evaluation of Elevation Data Uncertainty in Water Resources Modeling with GIS.” Water Resources Management.

[16] Yusof, K. W. and S. M. J. Baban (2000). Identifying Optimum Sites for locating Reservoirs employing Remotely Sensed Data and Geographical Information Systems. Asian Conference on Remote Sensing Taipei, Taiwan, www.GISdevelopment.net

[17] Ludwig, R. and P. Schneider (2006). "Validation of digital elevation models from SRTM X-SAR for applications in hydrologic modeling." ISPRS Journal of Photogrammetry and Remote Sensing 60(5): 339-358.

[18] Eiumnoh, A and Shrestha, P. 2000. Application of DEM Data to Landsat Image Classification: Evaluation in a Tropical Wet-Dry Landscape of Thailand. Photogrammetric Engineering \& Remote Sensing, 63 (10), 1195-1202.

[19] Howe, C. W.; Goemans, C. 2003. Water Transfer and their Impact: Lessons from Three Colorado Water Markets. Journal of American Water Resources Association (JAWRA) 39(5): 1055-1065

[20] Boxer, B. 2001. "Contradictions and Challenges in China's Water Police Development." Water International 26 (3): 335-341.

[21] Albiac J. 2002. Water Demand Management versus Water Supply Policy: the Ebro River Water Transfer. World Bank Water Forum 2002 Inter-Basin Transfers May 6-8, 2002.

[22] Vasudeva RPHV (2004). Environmental impact assessment of diversion weirs/check Dams in the triba area of Visakhapatnam district. Project report

[23] Ruud, N. C., T. Harter, A. W. Naugle, 2002. A conjunctive use groundwater-surface water flow model for the Tule River groundwater basin in the easterncentral San Joaquin Valley, California; in: Marino, M. A \& S. P. Simonovic, Integrated Water Resources Management, IAHS Publication No. 272, p. 167-174. . 